\title{
Utility of Ion-Mobility Spectrometry for Deducing Branching of Multiply Charged Glycans and Glycopeptides in a High- Throughput Positive ion LC-FLR-IMS-MS Workflow
}

Edward G. Pallister ${ }^{\dagger \dagger}$, Matthew S. F. Choo ${ }^{\dagger}$, Ian Walsh ${ }^{\dagger}$, Jien Nee Tai ${ }^{\dagger}$, Shi Jie Tay ${ }^{\dagger}$, Yuan Sheng Yang ${ }^{\dagger}$, Say Kong Ng ${ }^{\dagger}$, Pauline M. Rudd ${ }^{\dagger}$, Sabine L. Flitsch ${ }^{{ }^{*}}$ and Terry NguyenKhuong $^{\dagger *}$

$\dagger$ †ioprocessing Technology Institute, Agency for Science Technology and Research, Singapore

ISchool of Chemistry \& Manchester Institute of Biotechnology (MIB), The University of Manchester, United Kingdom 


\section{Contents}

Figures

Figure S1. FLR Chromatogram of typical RFMS-Labelled glycans from IgG. 3

Figure S2. CCSD plots of a) $m / z 968 F(6) A 2 G 1[M+2 H]^{2+}$ species b) $m / z 968 F(6) A 2 G 1^{\prime}[M+2 H]^{2+}$ species c) $m / z$ $979 \mathrm{~F}(6) A 2 \mathrm{G} 1[\mathrm{M}+\mathrm{Na}+\mathrm{H}]^{2+}$ species d) $m / z$ 979 $\mathrm{F}(6) A 2 \mathrm{G} 1{ }^{\prime}[\mathrm{M}+\mathrm{Na}+\mathrm{H}]^{2+}$ species 4

Figure S3. Mass spectrum from IMS-MS/MS analysis for a) Precursor m/z 968, F(6)A2G1 $[M+2 H]^{2+}$ species b) Precursor $\mathrm{m} / \mathrm{z}$ 979, $\mathrm{F}(6) \mathrm{A} 2 \mathrm{G} 1\left[\mathrm{M}+\mathrm{Na}+\mathrm{H}^{12+}\right.$ species. N.B. White circle indicates either a galactose or mannose hexose unit present in the product ion structure.

Figure S4. Triplicate overlay of CCSDs from $\mathrm{m} / \mathrm{z} 712$ product ions. Red - Triplicate CCSDs for the $m / z 712$ product ion of the $F(6) A 2 G 1$ isomer. Blue - Triplicate CCSDs for the $m / z 712$ product ion of the $F(6) A 2 G 1$ ' isomer.

Figure S5. FLR HILIC-LC trace of IgG glycopeptides following tryptic digestion of IgG.

Figure S6. CCSD plots from IMS-MS of IgG glycopeptide species with EEQYNSTYR peptide reducing terminus. a) CCSD of $m / z 1399[\mathrm{M}+2 \mathrm{H}]^{2+} \mathrm{F}(6) A 2 \mathrm{G} 1$ glycopeptide b) CCSD of $m / z 1399[\mathrm{M}+2 \mathrm{H}]^{2+}$ F(6)A2G1' glycopeptide c) CCSD of $m / z 1410[\mathrm{M}+\mathrm{Na}+\mathrm{H}]^{2+} \mathrm{F}(6) A 2 \mathrm{G} 1$ glycopeptide d) CCSD of $m / z$ $1410[\mathrm{M}+\mathrm{Na}+\mathrm{H}]^{2+} \mathrm{F}(6) A 2 \mathrm{G} 1$ ' glycopeptide e) CCSD of $m / z$ 933 [M+3H $]^{3+} \mathrm{F}(6) A 2 \mathrm{G} 1$ glycopeptide f) CCSD of $m / z 933[\mathrm{M}+3 \mathrm{H}]^{3+} \mathrm{F}(6) A 2 \mathrm{G} 1$ ' glycopeptide.

Figure S7. Example FLR assignments of RFMS-Glycans released from CHO AAT. .............................. 8

Figure S8. CCSD from IMS-MS intact analysis of a) $m / z 1115 \mathrm{~F}(6) A 2 \mathrm{G} 1 \mathrm{~S} 1[\mathrm{M}+2 \mathrm{H}]^{2+}$ species b) $\mathrm{m} / \mathrm{z}$ $1115 \mathrm{~F}(6) A 2 \mathrm{G} 1$ 'S1 $[\mathrm{M}+2 \mathrm{H}]^{2+}$ species c) $m / z 1207 \mathrm{~F}(6) A 2 \mathrm{G} 1 \mathrm{~S} 1[\mathrm{M}+\mathrm{Na}+\mathrm{H}]^{2+}$ species d) $m / z 1207$ $\mathrm{F}(6) A 2 \mathrm{G} 1$ 'S1 $[\mathrm{M}+\mathrm{Na}+\mathrm{H}]^{2+}$ species.

Figure S9. CCSD from IMS-MS intact analysis of a) $m / z 989 F(6) A 3[M+2 H]^{2+}$ species b) $m / z 989$ $\mathrm{F}(6) A 2 B[\mathrm{M}+2 \mathrm{H}]^{2+}$ species c) $m / z 1000 \mathrm{~F}(6) \mathrm{A} 3[\mathrm{M}+\mathrm{Na}+\mathrm{H}]^{2+}$ species d) $m / z 1000 \mathrm{~F}(6) A 2 B$ $[\mathrm{M}+\mathrm{Na}+\mathrm{H}]^{2+}$ species.

Figure S10. CCSD plots from IMS-MS of IgG glycopeptide species with EEQYNSTYR peptide reducing terminus. a) CCSD of $m / z 1420[\mathrm{M}+2 \mathrm{H}]^{2+} \mathrm{F}(6) \mathrm{A} 3$ glycopeptide b) CCSD of $m / z 1420[\mathrm{M}+2 \mathrm{H}]^{2+}$ $\mathrm{F}(6) A 2 B$ glycopeptide c) CCSD of $m / z 1431[\mathrm{M}+\mathrm{Na}+\mathrm{H}]^{2+} \mathrm{F}(6) \mathrm{A} 3$ glycopeptide d) CCSD of $m / z 1431$ $[\mathrm{M}+\mathrm{Na}+\mathrm{H}]^{2+} \mathrm{F}(6) A 2 B$ glycopeptide e) CCSD of $\mathrm{m} / \mathrm{z} 947[\mathrm{M}+3 \mathrm{H}]^{3+} \mathrm{F}(6) \mathrm{A} 3$ glycopeptide f) CCSD of $\mathrm{m} / \mathrm{z}$ $947[\mathrm{M}+3 \mathrm{H}]^{3+} \mathrm{F}(6) \mathrm{A} 2 \mathrm{~B}$ glycopeptide.

Figure S11. CCSD of $m / z 712$ product ion from the IMS-MS/MS glycan sequencing analysis of the $\mathrm{F}(6) \mathrm{A} 3[\mathrm{M}+\mathrm{Na}+\mathrm{H}]^{2+}$ glycopeptide species.

Figure S12. CCSD of $m / z 712$ product ion from the IMS-MS/MS glycan sequencing analysis of the $\mathrm{F}(6) A 2 B[\mathrm{M}+\mathrm{Na}+\mathrm{H}]^{2+}$ glycopeptide species.

Figure S13. CCSDs of $\mathrm{m} / \mathrm{z} 550$ product ion from the IMS-MS/MS glycan sequencing analysis from a) $\mathrm{F}(6) A 3$ glycopeptide $[\mathrm{M}+\mathrm{Na}+\mathrm{H}]^{2+}$ species b) $\mathrm{F}(6) A 2 B$ glycopeptide $[\mathrm{M}+\mathrm{Na}+\mathrm{H}]^{2+}$ species.

Figure S14. CCSD obtained for four EIC peaks A, B, C and D observed during intact IMS-MS analysis of CHO AAT released RFMS released $\mathrm{N}$-glycans. a) CCSD of $\mathrm{m} / \mathrm{z} 1071[\mathrm{M}+2 \mathrm{H}]^{2+}$ for peak A b) CCSD of $m / z 1071[\mathrm{M}+2 \mathrm{H}]^{2+}$ for peak B c) CCSD of $m / z 1071[\mathrm{M}+2 \mathrm{H}]^{2+}$ for peak C d) CCSD of $m / z 1071$ $[\mathrm{M}+2 \mathrm{H}]^{2+}$ for peak D e) CCSD of $m / z 1082[\mathrm{M}+\mathrm{Na}+\mathrm{H}]^{2+}$ for peak A f) CCSD of $m / z 1082[\mathrm{M}+\mathrm{Na}+\mathrm{H}]^{2+}$ for peak B g) CCSD of $m / z 1082[\mathrm{M}+\mathrm{Na}+\mathrm{H}]^{2+}$ for peak $\mathrm{C}$ h) CCSD of $m / z 1082[\mathrm{M}+\mathrm{Na}+\mathrm{H}]^{2+}$ for peak D...14 Figure S15. CCSD of $m / z 550$ product ion from precursor $m / z 1082[\mathrm{M}+\mathrm{Na}+\mathrm{H}]^{2+}$ of the four EIC peaks A, B, C and D observed during RFMS glycan released anlaysis of CHO AAT glycans. a) CCSD of $m / z$ 550 product ion from precursor $m / z 1082[\mathrm{M}+\mathrm{Na}+\mathrm{H}]^{2+}$ for peak $A$ b) CCSD of $\mathrm{m} / \mathrm{z} 550$ product ion from precursor $m / z 1082[\mathrm{M}+\mathrm{Na}+\mathrm{H}]^{2+}$ from peak $\mathrm{B} \mathrm{C}$ ) CCSD of $\mathrm{m} / \mathrm{z} 550$ product ion from precursor $m / z 1082[\mathrm{M}+\mathrm{Na}+\mathrm{H}]^{2+}$ from peak $\mathrm{C}$ d) CCSD of $m / z 550$ product ion from precursor $m / z 1082$ $[\mathrm{M}+\mathrm{Na}+\mathrm{H}]^{2+}$ from peak $\mathrm{D}$.

Figure S16. CCSD of $m / z 915$ product ion from precursor $m / z 1082[\mathrm{M}+\mathrm{Na}+\mathrm{H}]^{2+}$ of the four EIC peaks A, B, C and D observed during RFMS glycan released anlaysis of CHO AAT glycans. a) CCSD of $\mathrm{m} / \mathbf{z}$ 915 product ion from precursor $m / z 1082[\mathrm{M}+\mathrm{Na}+\mathrm{H}]^{2+}$ for peak $A$ b) CCSD of $\mathrm{m} / \mathrm{z} 915$ product ion from precursor $m / z 1082[\mathrm{M}+\mathrm{Na}+\mathrm{H}]^{2+}$ from peak B c) CCSD of $m / z 915$ product ion from precursor 
$m / z 1082[\mathrm{M}+\mathrm{Na}+\mathrm{H}]^{2+}$ from peak $\mathrm{C}$ d) CCSD of $m / z 915$ product ion from precursor $m / z 1082$

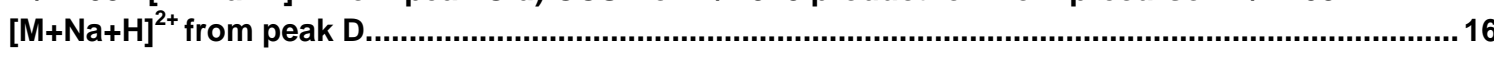

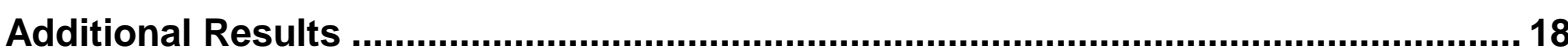

Figure S17. Sialylated glycan structures a) F(6)A2G2S1 b)F(6)A2G2S1'........................................19

Figure S18. CCSD from IMS-MS intact analysis of a) $m / z 1196 \mathrm{~F}(6) A 2 \mathrm{G} 2 \mathrm{~S} 1[\mathrm{M}+2 \mathrm{H}]^{2+}$ species b) $m / z 1196 \mathrm{~F}(6) A 2 \mathrm{G} 2 \mathrm{~S} 1^{\prime}[\mathrm{M}+2 \mathrm{H}]^{2+}$ species c) $m / z 1207 \mathrm{~F}(6) \mathrm{A} 2 \mathrm{G} 2 \mathrm{~S} 1[\mathrm{M}+\mathrm{Na}+\mathrm{H}]^{2+}$ species d) $m / z 1207$

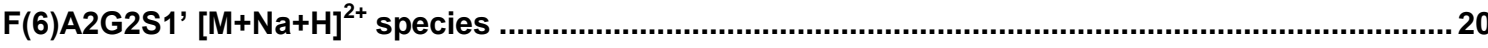

Tables 22

Table S1. All potential product ions with $\mathrm{m} / \mathrm{z} 712$ from fragmentation of $\mathrm{F}(6) \mathrm{A} 2 \mathrm{G} 1[\mathrm{M}+\mathrm{Na}+\mathrm{H}]^{2+}$ species.

Table S2. All potential product ions with $\mathrm{m} / \mathrm{z} 712$ from fragmentation of $\mathrm{F}(6) \mathrm{A} 2 \mathrm{G} 1^{\prime}[\mathrm{M}+\mathrm{Na}+\mathrm{H}]^{2+}$ species.

\section{Figures}

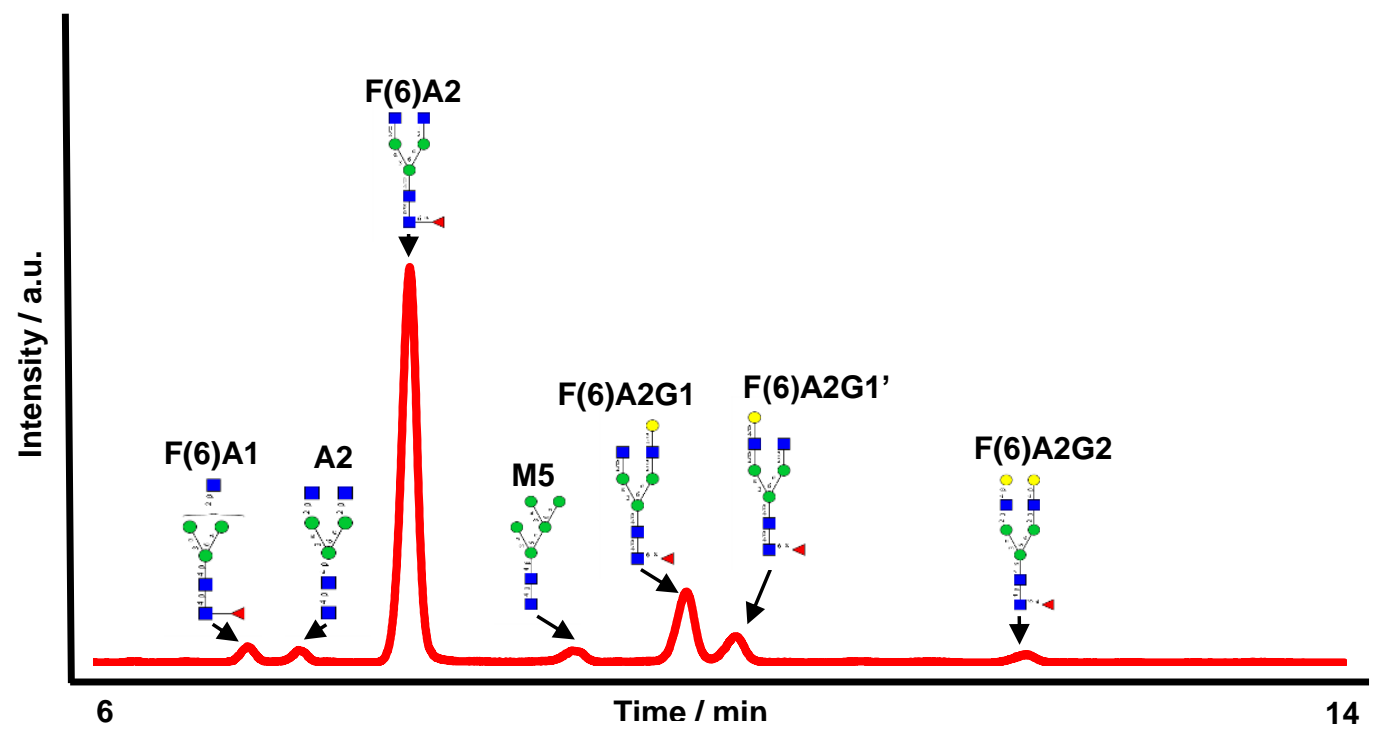

Figure S1. FLR Chromatogram of typical RFMS-Labelled glycans from IgG. 


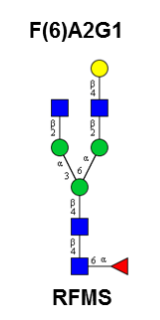

$[\mathrm{M}+2 \mathrm{H}]^{2+} m / z 968$

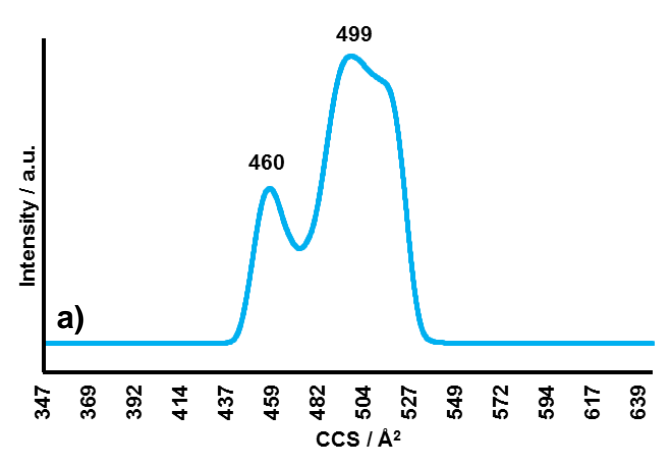

$[\mathrm{M}+\mathrm{Na}+\mathrm{H}]^{2+} \mathrm{m} / \mathrm{z} 979$

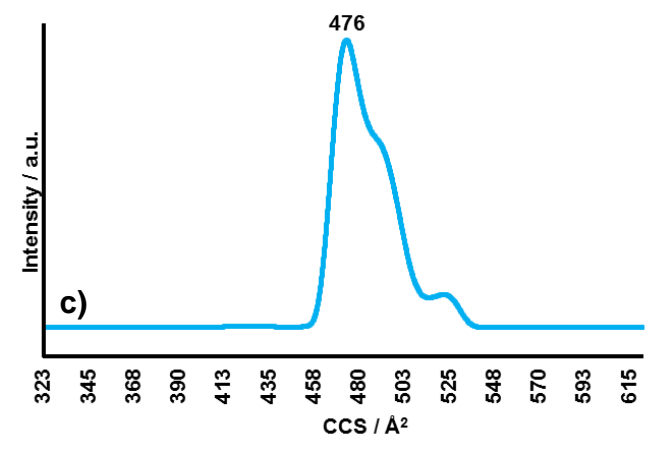

F(6)A2G1'

(

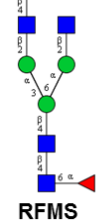

$[\mathrm{M}+2 \mathrm{H}]^{2+} \mathrm{m} / \mathrm{z} 968$

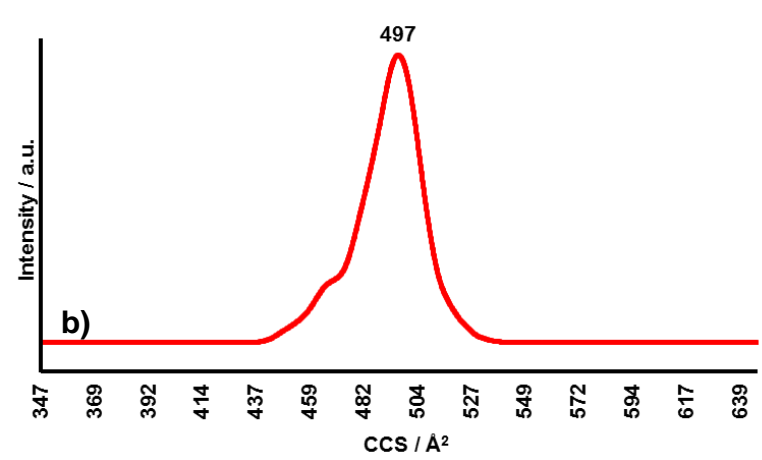

$[\mathrm{M}+\mathrm{Na}+\mathrm{H}]^{2+} \mathrm{m} / \mathrm{z} 979$

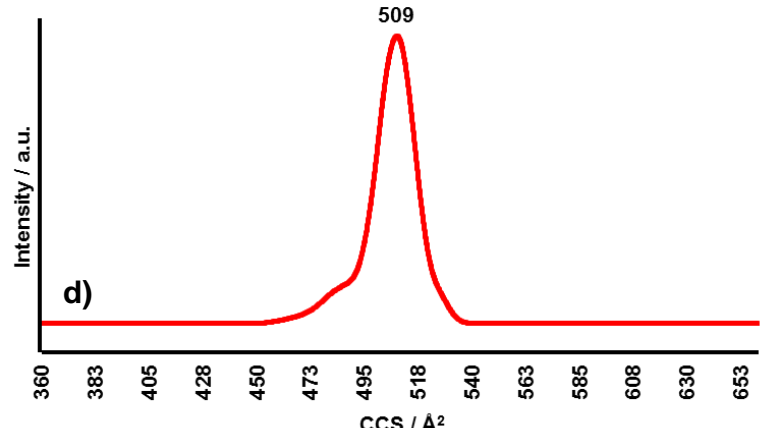

Figure S2. CCSD plots of a) $m / z 968 F(6) A 2 G 1[M+2 H]^{2+}$ species b) $m / z$ 968 $F(6) A 2 G 11^{\prime}[M+2 H]^{2+}$ species c) $m / z$ $979 \mathrm{~F}(6) A 2 \mathrm{G} 1[\mathrm{M}+\mathrm{Na}+\mathrm{H}]^{2+}$ species d) $m / z$ 979 $F(6) A 2 \mathrm{G} 1^{\prime}[\mathrm{M}+\mathrm{Na}+\mathrm{H}]^{2+}$ species 


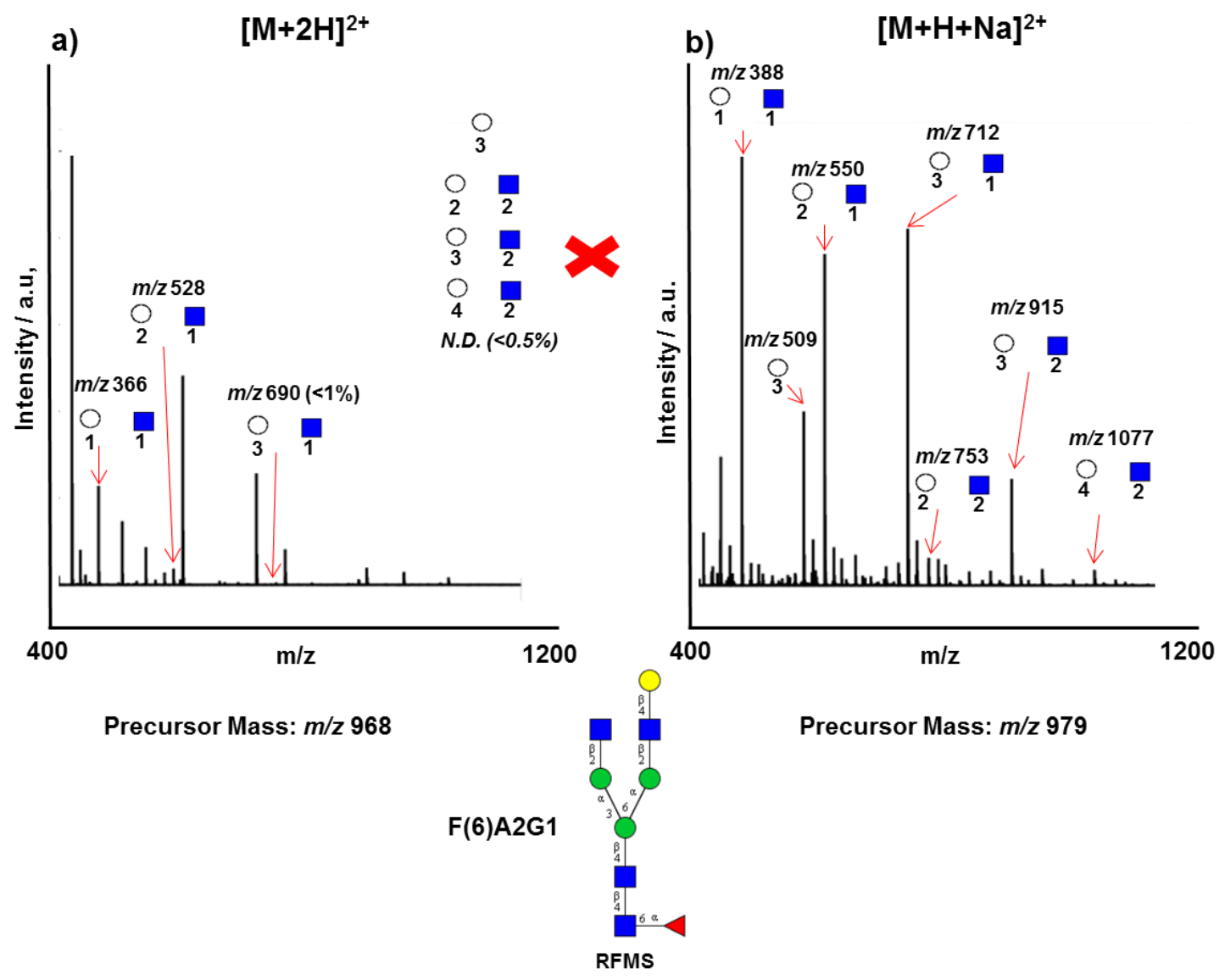

Figure S3. Mass spectrum from IMS-MS/MS analysis for a) Precursor m/z 968, F(6)A2G1 $[M+2 H]^{2+}$ species $^{2}$ b) Precursor m/z 979, F(6)A2G1 $\left[\mathrm{M}+\mathrm{Na}+\mathrm{H}^{2+}\right.$ species. N.B. White circle indicates either a galactose or mannose hexose unit present in the product ion structure.

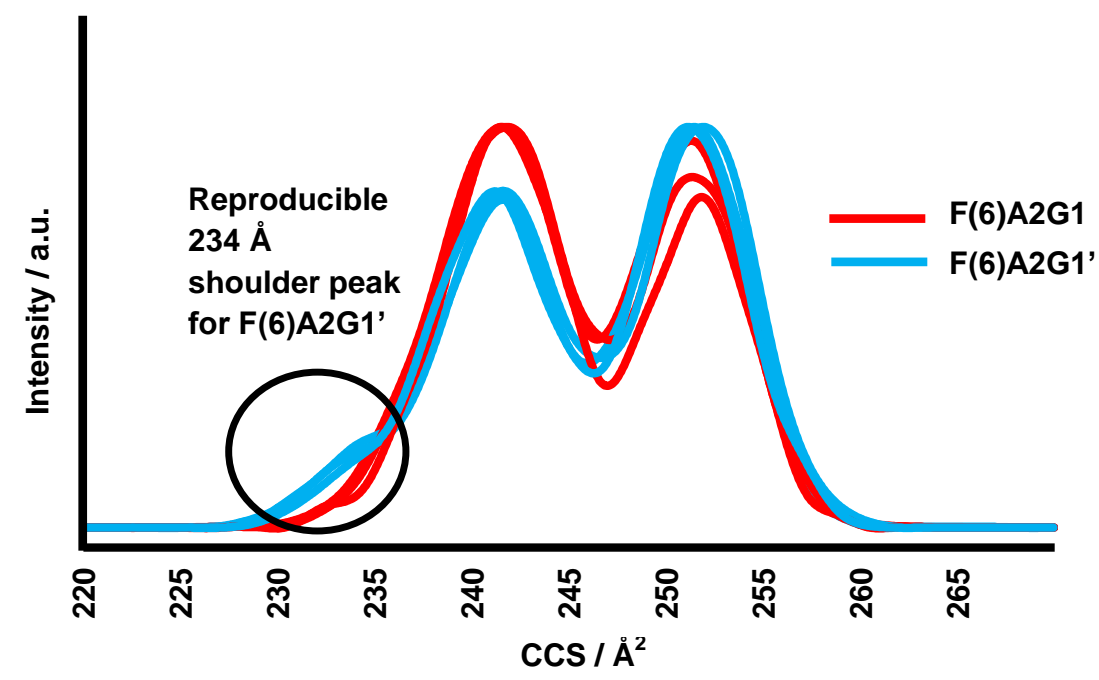

Figure S4. Triplicate overlay of CCSDs from $\mathrm{m} / \mathrm{z} 712$ product ions. Red - Triplicate CCSDs for the $m / z 712$ product ion of the $F(6) A 2 G 1$ isomer. Blue - Triplicate CCSDs for the $m / z 712$ product ion of the $F(6) A 2 G 1$ ' isomer. 


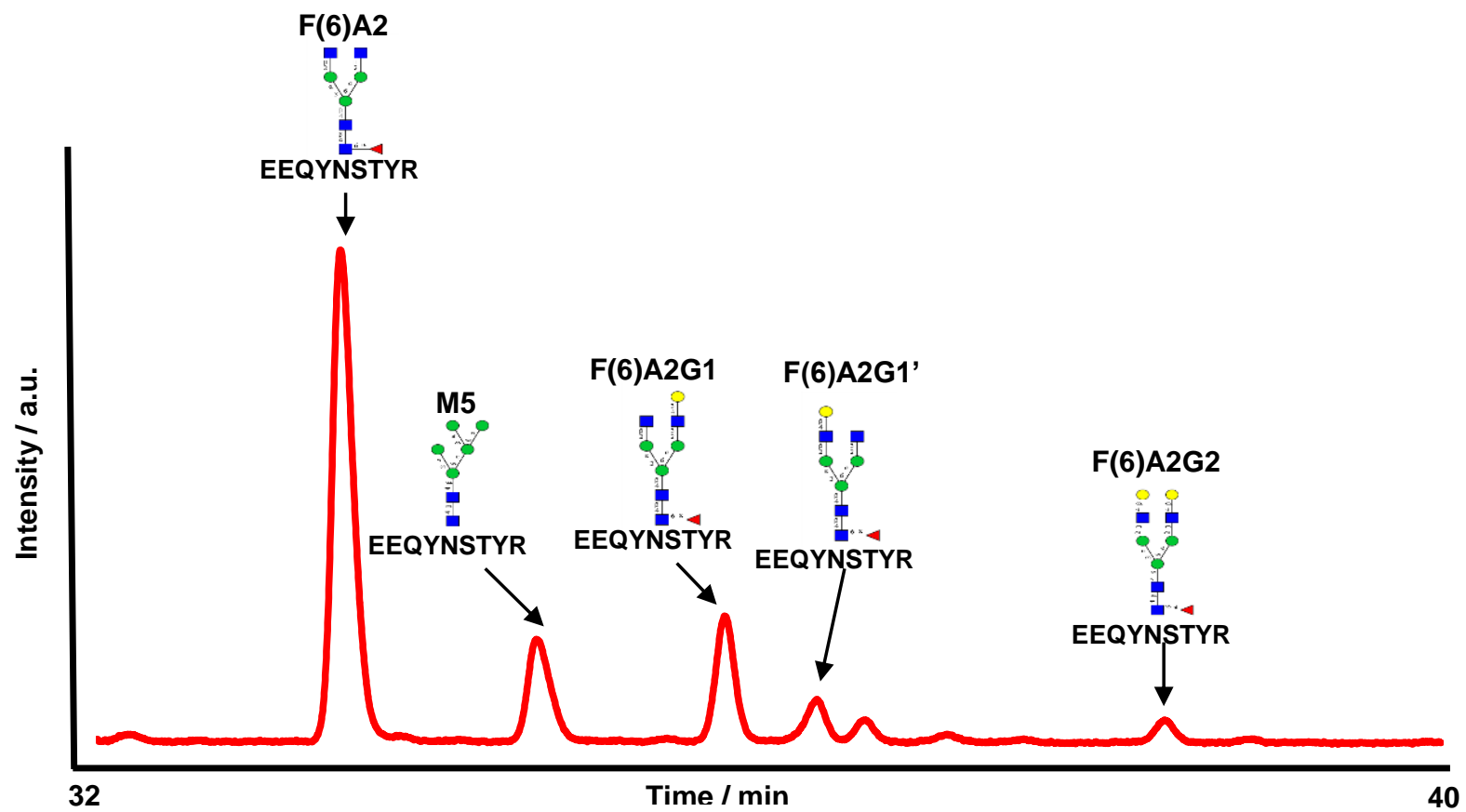

Figure S5. FLR HILIC-LC trace of IgG glycopeptides following tryptic digestion of IgG. 


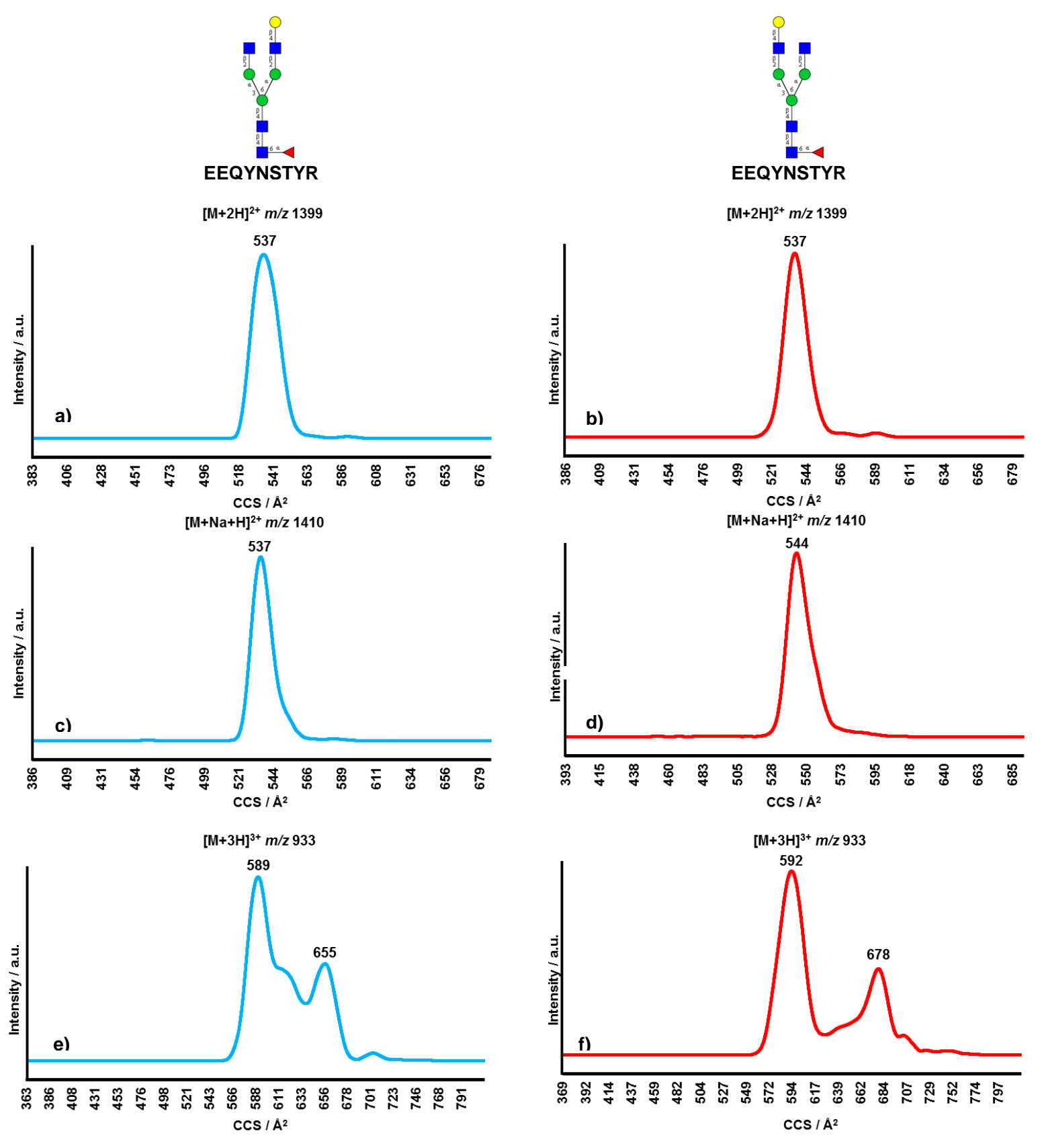

Figure S6. CCSD plots from IMS-MS of IgG glycopeptide species with EEQYNSTYR peptide reducing terminus. a) CCSD of $m / z 1399[\mathrm{M}+2 \mathrm{H}]^{2+} \mathrm{F}(6) A 2 \mathrm{G} 1$ glycopeptide b) CCSD of $m / z 1399[\mathrm{M}+2 \mathrm{H}]^{2+} \mathrm{F}(6) A 2 \mathrm{G} 1$, glycopeptide c) CCSD of $m / z 1410[\mathrm{M}+\mathrm{Na}+\mathrm{H}]^{2+} \mathrm{F}(6) A 2 \mathrm{G} 1$ glycopeptide d) CCSD of $m / z 1410[\mathrm{M}+\mathrm{Na}+\mathrm{H}]^{2+}$ F(6)A2G1' glycopeptide e) CCSD of $m / z 933[M+3 H]^{3+} F(6) A 2 G 1$ glycopeptide f) CCSD of $m / z 933$ $[\mathrm{M}+3 \mathrm{H}]^{3+} \mathrm{F}(6) \mathrm{A} 2 \mathrm{G} 1$ ' glycopeptide. 


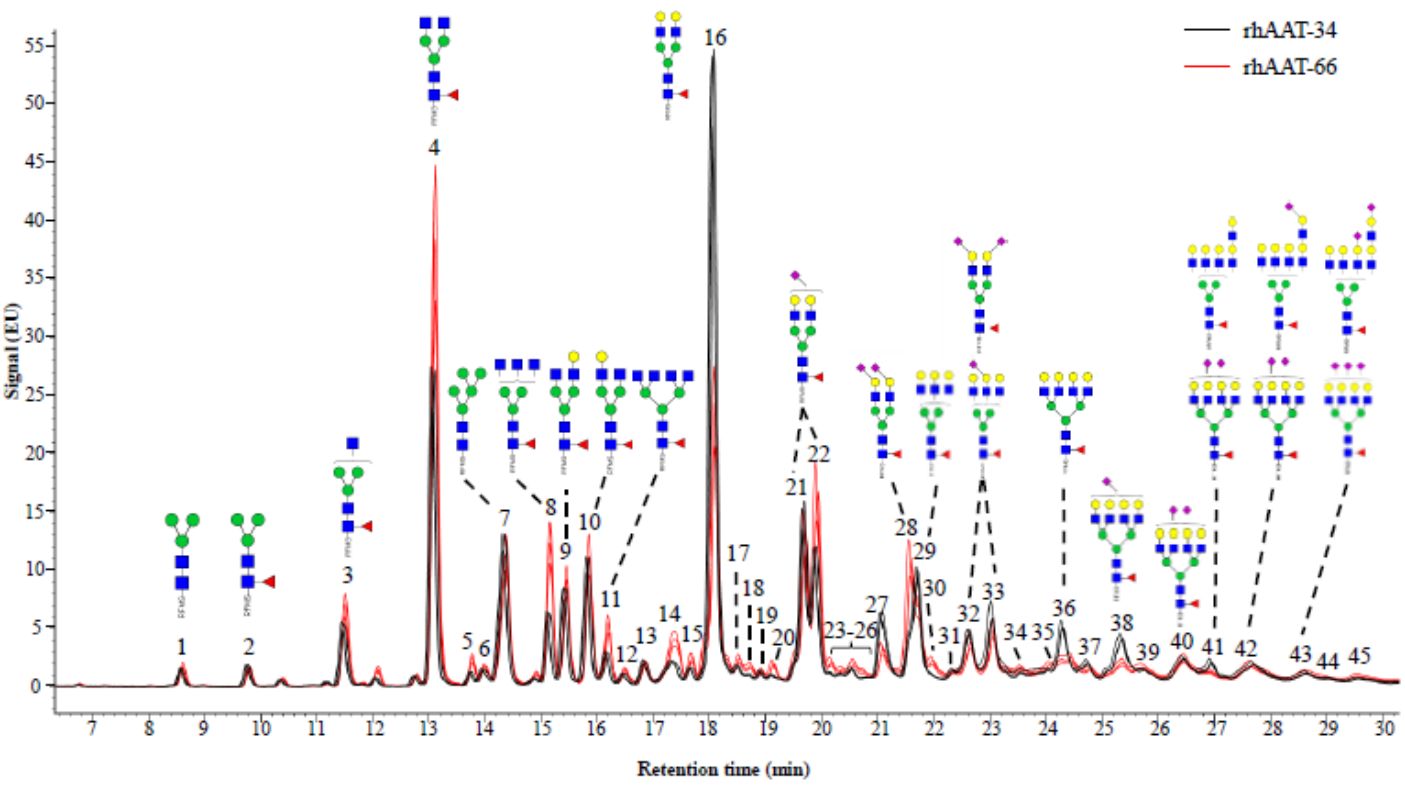

Figure S7. Example FLR assignments of RFMS-Glycans released from CHO AAT. 
$\mathrm{F}(6) A 2 G 1 S 1$

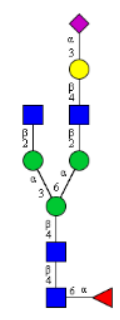

RFMS
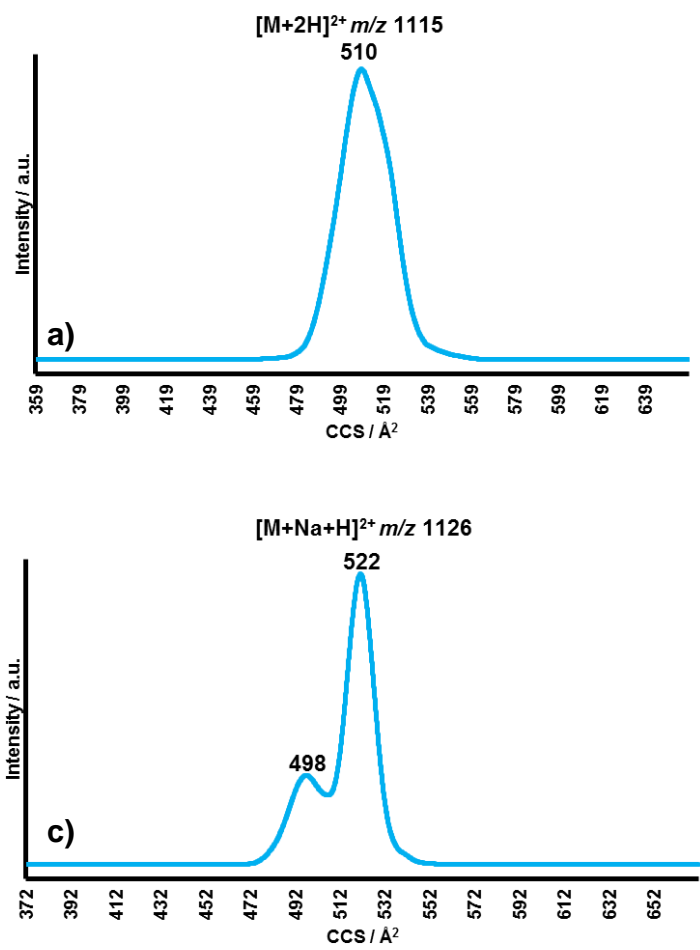

F(6)A2G1'S1

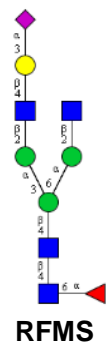

$[\mathrm{M}+2 \mathrm{H}]^{2+} \mathrm{m} / \mathrm{z} 1115$

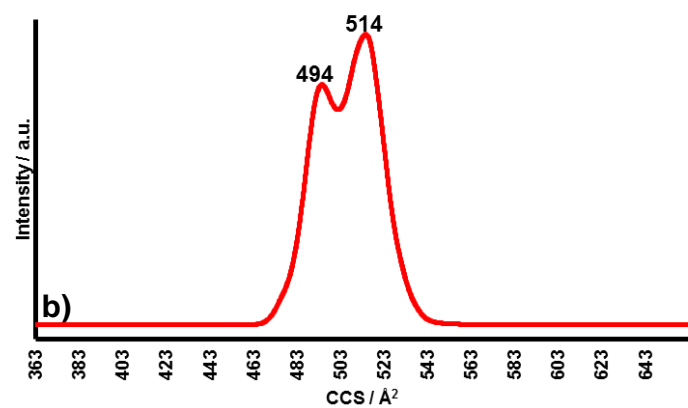

$[\mathrm{M}+\mathrm{Na}+\mathrm{H}]^{2+} \mathrm{m} / \mathrm{z} 1126$

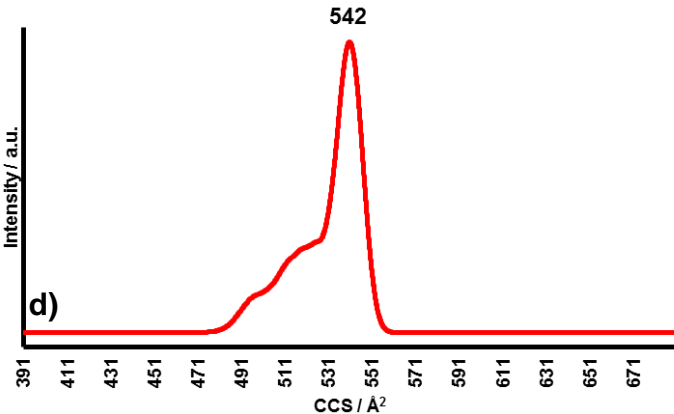

Figure S8. CCSD from IMS-MS intact analysis of a) $m / z 1115 \mathrm{~F}(6) A 2 \mathrm{G} 1 \mathrm{~S} 1[\mathrm{M}+2 \mathrm{H}]^{2+} \mathrm{species}^{\mathrm{b}} \mathrm{m} \mathrm{m} / \mathrm{z}$ $1115 \mathrm{~F}(6) A 2 \mathrm{G} 1$ 'S1 $[\mathrm{M}+2 \mathrm{H}]^{2+}$ species c) $\mathrm{m} / \mathrm{z} 1207 \mathrm{~F}(6) A 2 \mathrm{G} 1 \mathrm{~S} 1[\mathrm{M}+\mathrm{Na}+\mathrm{H}]^{2+}$ species d) $\mathrm{m} / \mathrm{z} 1207$ $\mathrm{F}(6) A 2 \mathrm{G} 1$ 'S1 $[\mathrm{M}+\mathrm{Na}+\mathrm{H}]^{2+}$ species. 

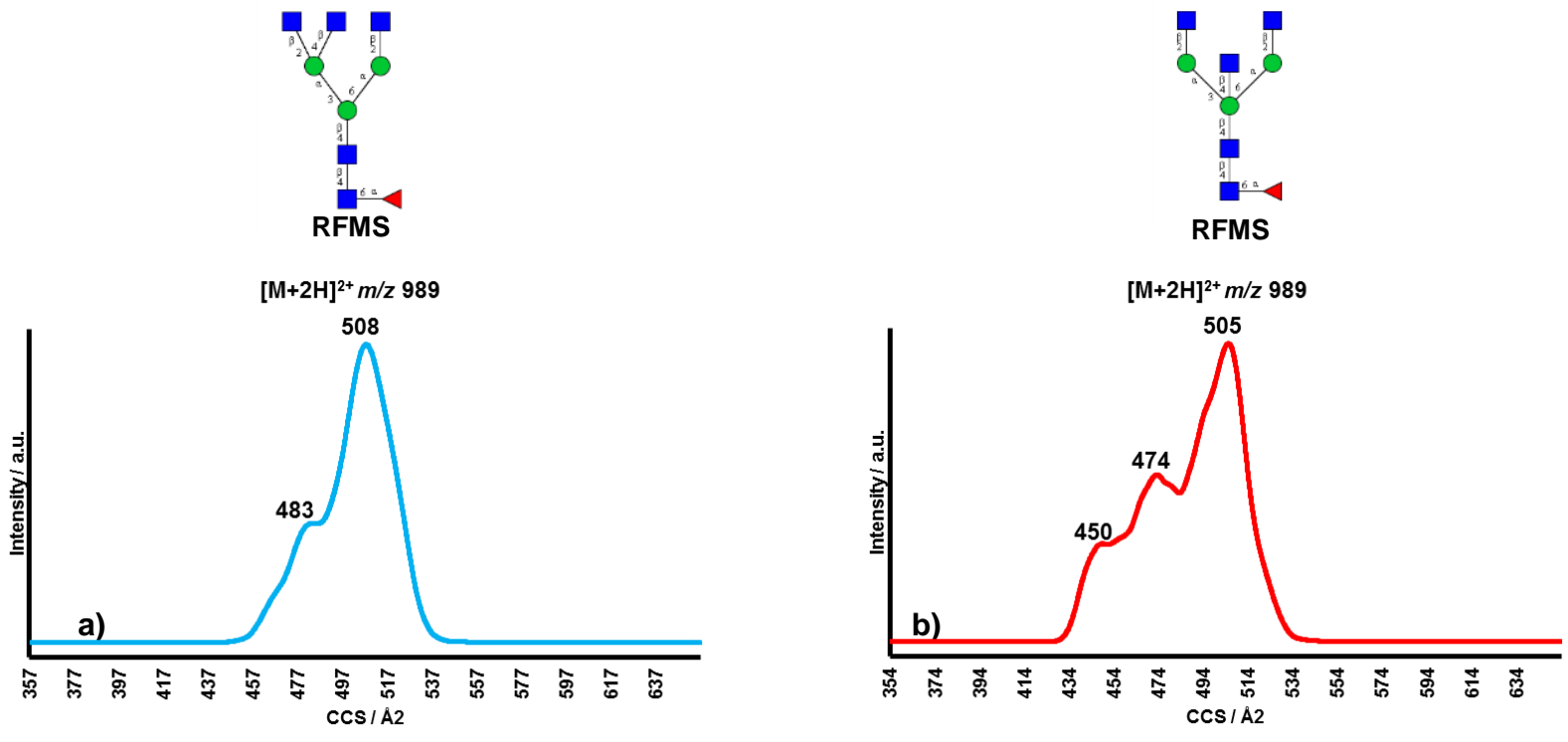

$[\mathrm{M}+\mathrm{Na}+\mathrm{H}]^{2+} \mathrm{m} / \mathrm{z} 1000$

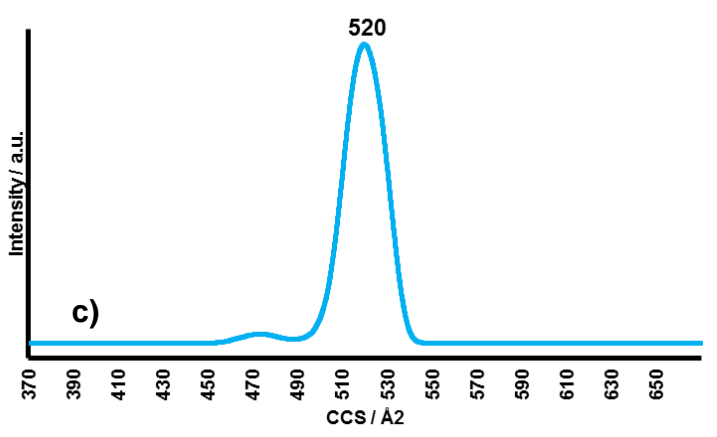

$[\mathrm{M}+\mathrm{Na}+\mathrm{H}]^{2+} \mathrm{m} / \mathrm{z} 1000$

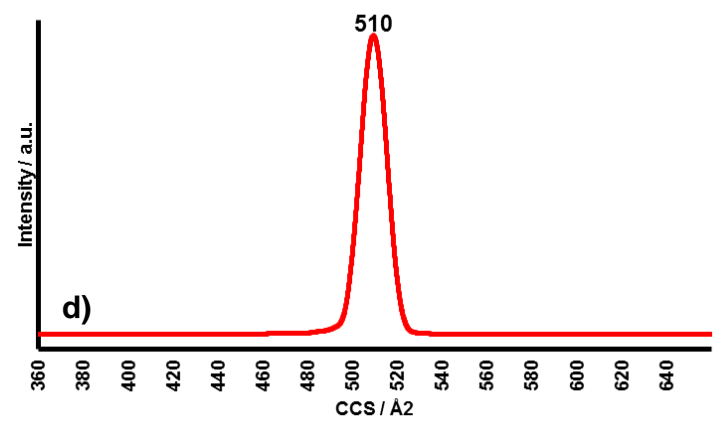

Figure S9. CCSD from IMS-MS intact analysis of a) $m / z 989 F(6) A 3[M+2 H]^{2+}$ species b) $m / z 989 F(6) A 2 B$ $[\mathrm{M}+2 \mathrm{H}]^{2+}$ species c) $m / z 1000 \mathrm{~F}(6) \mathrm{A} 3[\mathrm{M}+\mathrm{Na}+\mathrm{H}]^{2+}$ species d) $m / z 1000 \mathrm{~F}(6) A 2 B[\mathrm{M}+\mathrm{Na}+\mathrm{H}]^{2+}$ species. 


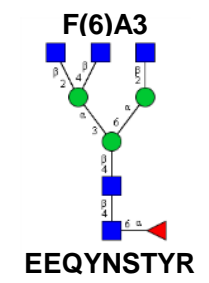

$[\mathrm{M}+2 \mathrm{H}]^{2+} \mathrm{m} / \mathrm{z} \quad 1419$

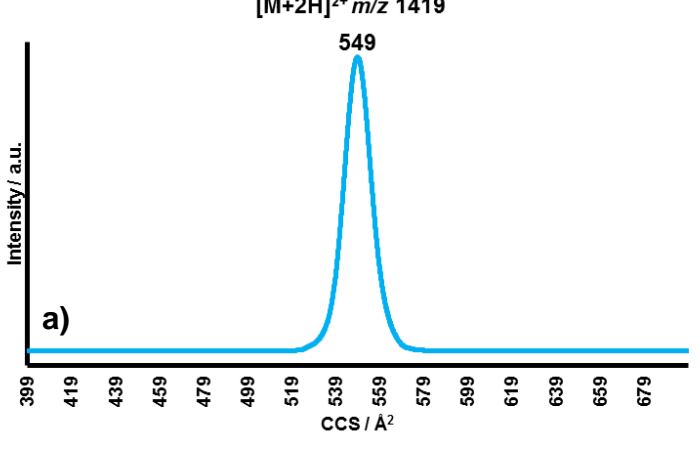

$[\mathrm{M}+\mathrm{Na}+\mathrm{H}]^{2+} \mathrm{m} / \mathrm{z} 1430$
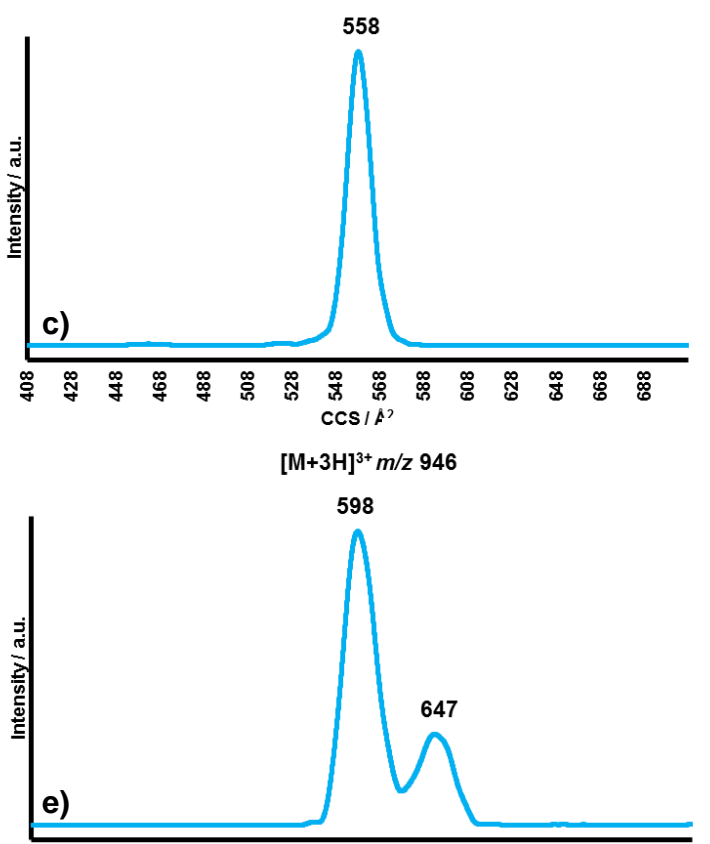

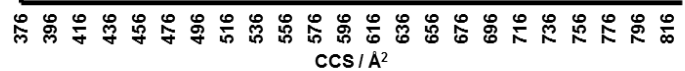
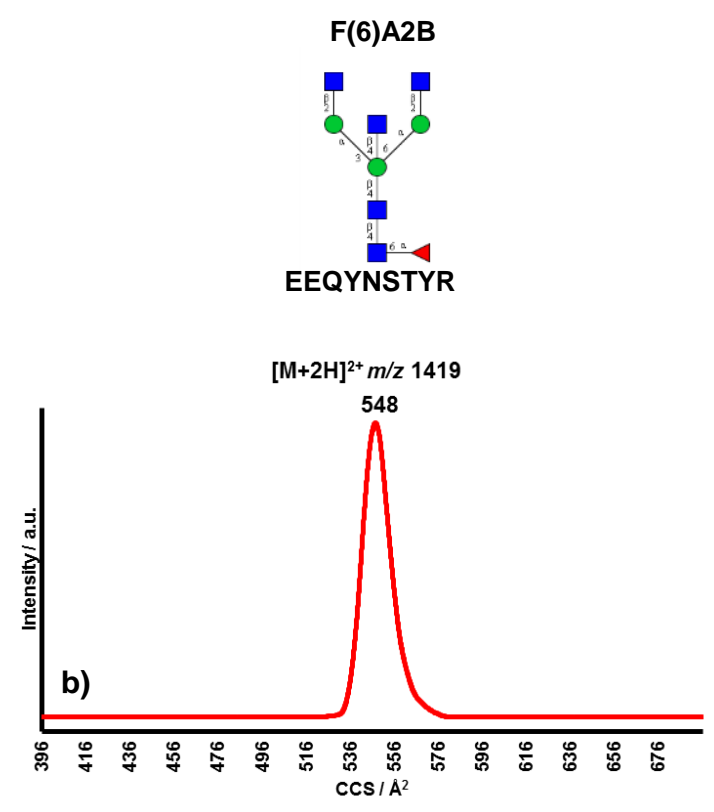

$[\mathrm{M}+\mathrm{Na}+\mathrm{H}]^{2+} m / z 1430$

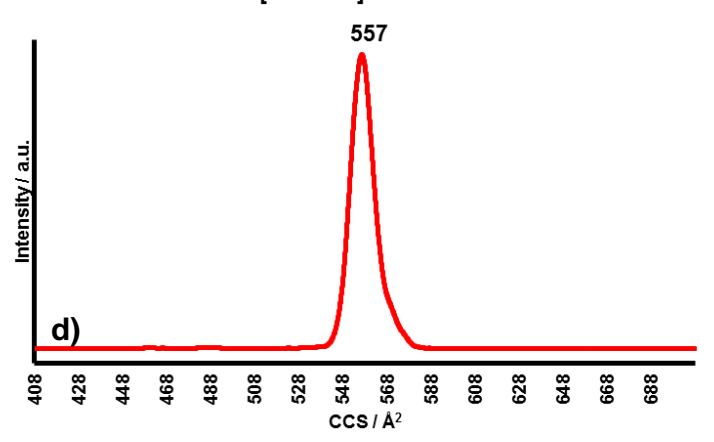

$[\mathrm{M}+3 \mathrm{H}]^{3+} \mathrm{m} / \mathrm{z} 946$

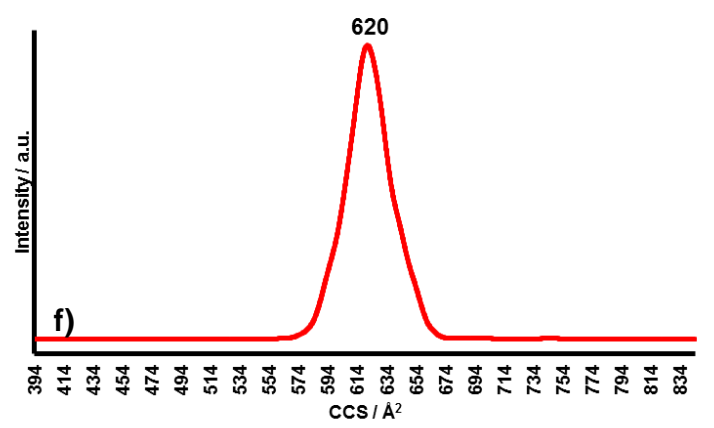

Figure S10. CCSD plots from IMS-MS of IgG glycopeptide species with EEQYNSTYR peptide reducing terminus. a) CCSD of $m / z 1420[M+2 H]^{2+} F(6) A 3$ glycopeptide b) CCSD of $m / z 1420[M+2 H]^{2+} F(6) A 2 B$ glycopeptide c) CCSD of $m / z 1431[\mathrm{M}+\mathrm{Na}+\mathrm{H}]^{2+} \mathrm{F}(6) A 3$ glycopeptide d) CCSD of $m / z 1431[\mathrm{M}+\mathrm{Na}+\mathrm{H}]^{2+}$ $\mathrm{F}(6) A 2 B$ glycopeptide e) CCSD of $m / z 947[\mathrm{M}+3 \mathrm{H}]^{3+} \mathrm{F}(6) A 3$ glycopeptide f) CCSD of $\mathrm{m} / \mathrm{z} 947[\mathrm{M}+3 \mathrm{H}]^{3+}$ F(6)A2B glycopeptide 


$$
(3 x \bigcirc+1 x \square)
$$

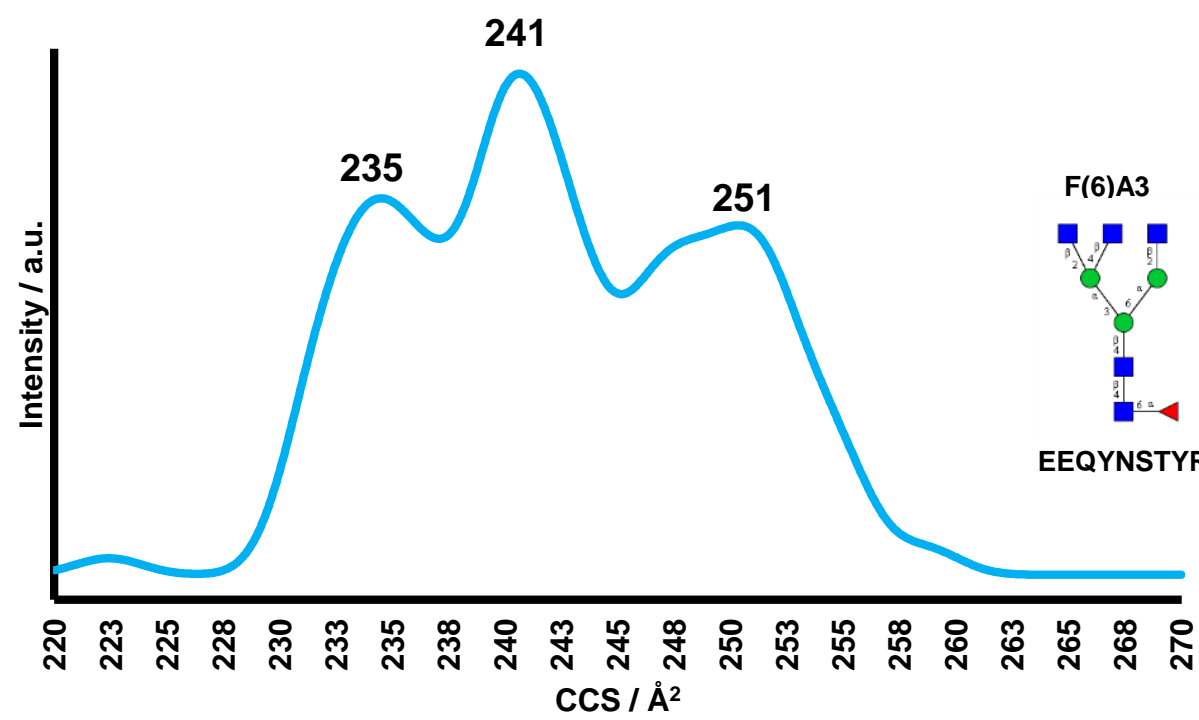

Figure S11. CCSD of $m / z 712$ product ion from the IMS-MS/MS glycan sequencing analysis of the $\mathrm{F}(6) \mathrm{A} 3[\mathrm{M}+\mathrm{Na}+\mathrm{H}]^{2+}$ glycopeptide species.

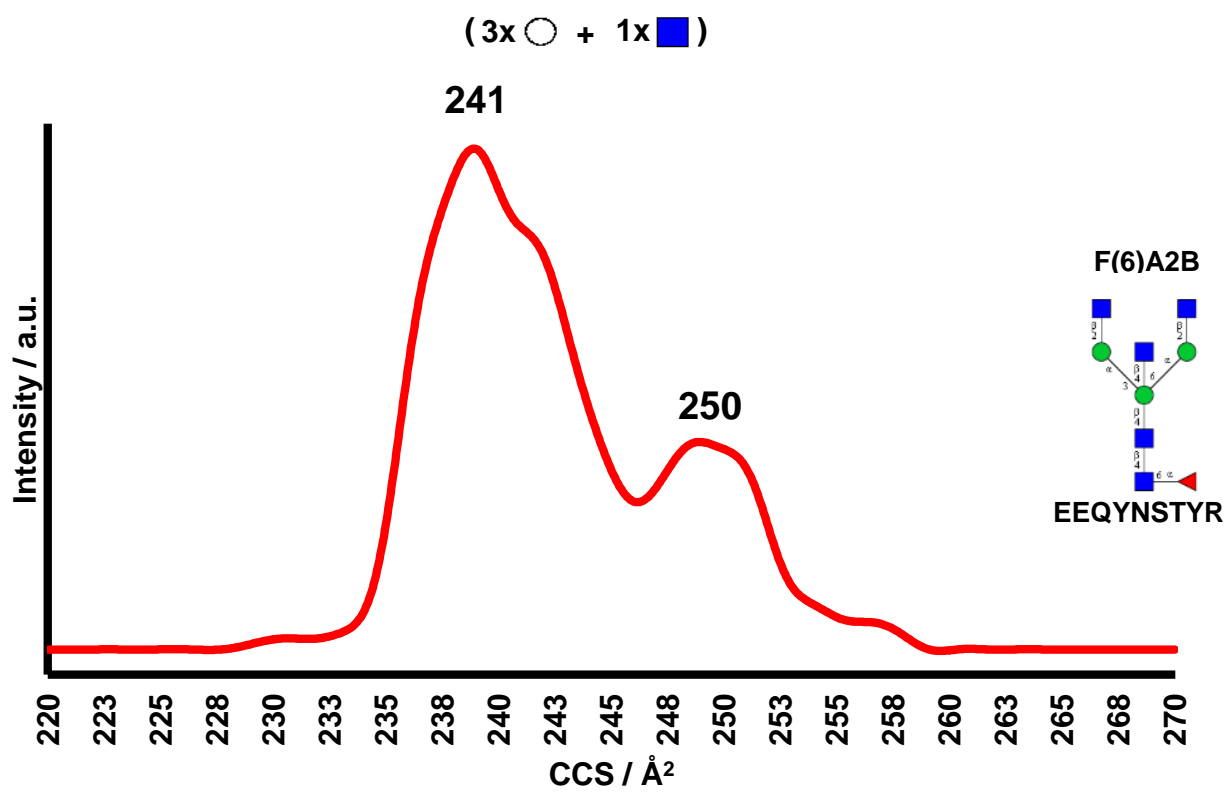

Figure S12. CCSD of $m / z 712$ product ion from the IMS-MS/MS glycan sequencing analysis of the $\mathrm{F}(6) \mathrm{A} 2 \mathrm{~B}[\mathrm{M}+\mathrm{Na}+\mathrm{H}]^{2+}$ glycopeptide species. 


$$
(2 x \bigcirc+1 x \square)
$$

$[\mathrm{M}+\mathrm{Na}]^{+} \mathrm{m} / \mathbf{z} 550$

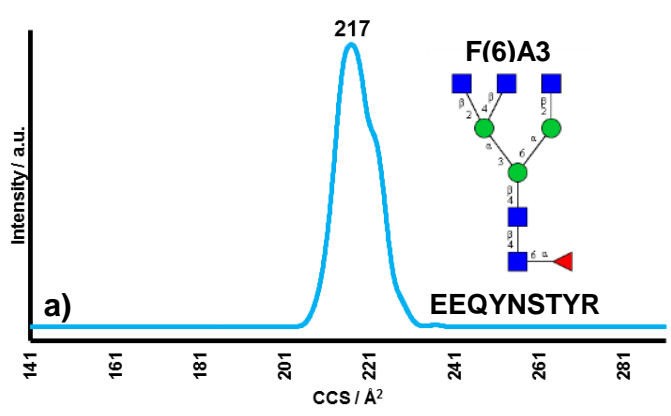

$[\mathrm{M}+\mathrm{Na}]^{+} \mathrm{m} / \mathrm{z} 550$

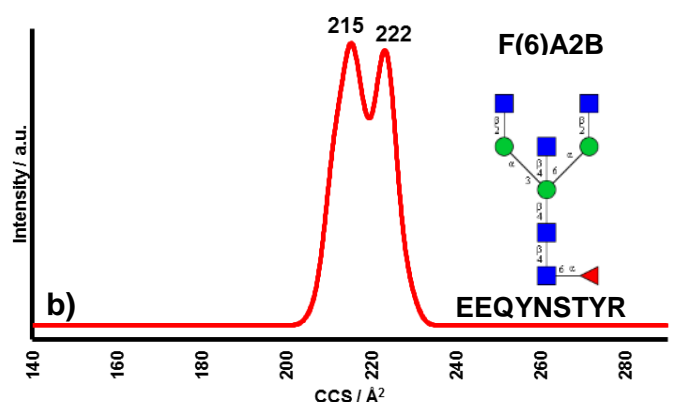

Figure S13. CCSDs of $\mathrm{m} / \mathrm{z} 550$ product ion from the IMS-MS/MS glycan sequencing analysis from a) $\mathrm{F}(6) A 3$ glycopeptide $[\mathrm{M}+\mathrm{Na}+\mathrm{H}]^{2+}$ species b) $\mathrm{F}(6) \mathrm{A} 2 \mathrm{~B}$ glycopeptide $[\mathrm{M}+\mathrm{Na}+\mathrm{H}]^{2+}$ species. 
$[\mathrm{M}+\mathbf{2 H}]^{2+} \mathrm{m} / \mathrm{Z} \mathbf{1 0 7 1}$

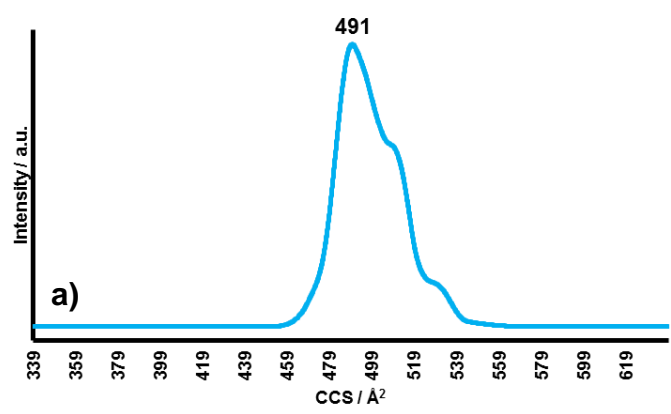

$[\mathrm{M}+2 \mathrm{H}]^{2+} \mathrm{m} / \mathrm{z} 1071$

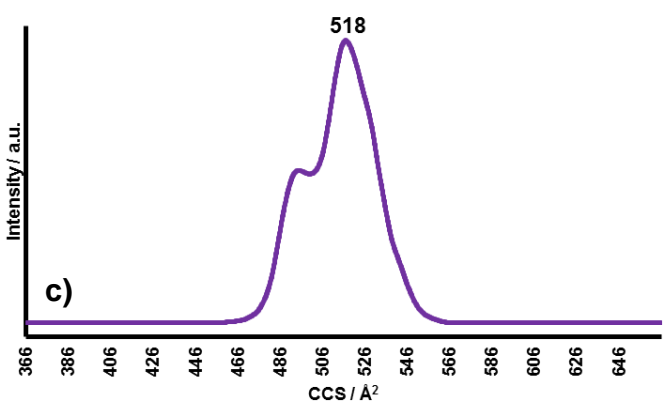

$[\mathrm{M}+\mathrm{Na}+\mathrm{H}]^{2+} \mathrm{m} / \mathrm{z} 1082$

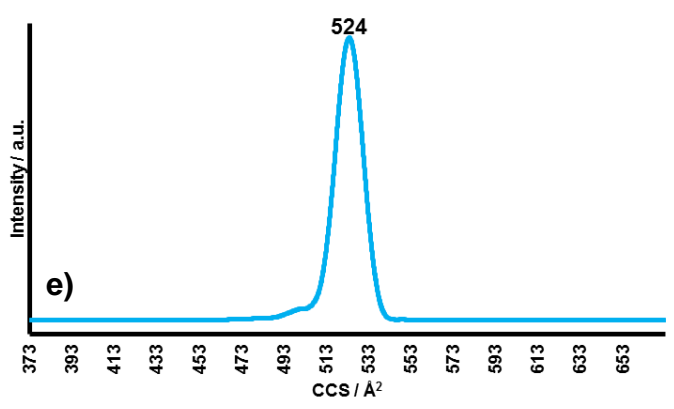

$[\mathrm{M}+\mathrm{Na}+\mathrm{H}]^{2+} \mathrm{m} / \mathrm{z} 1082$

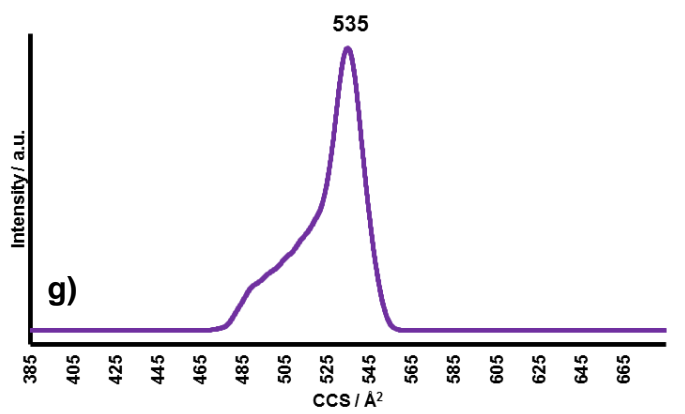

$[\mathrm{M}+2 \mathrm{H}]^{2+} \mathrm{m} / \mathrm{z} 1071$

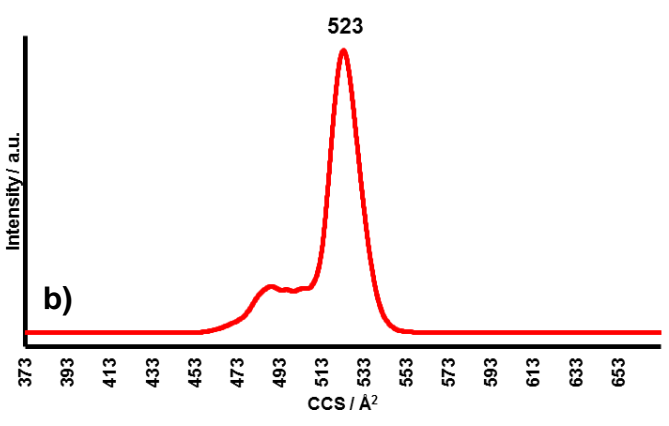

$[\mathrm{M}+2 \mathrm{H}]^{2+} \mathrm{m} / \mathrm{z} \quad 1071$

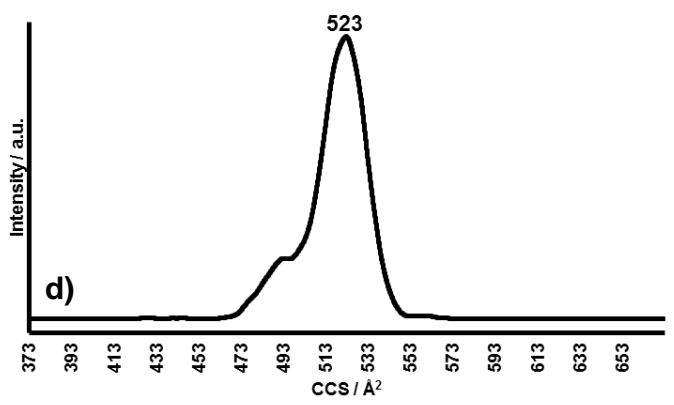

$[\mathrm{M}+\mathrm{Na}+\mathrm{H}]^{2+} \mathrm{m} / \mathrm{z} 1082$

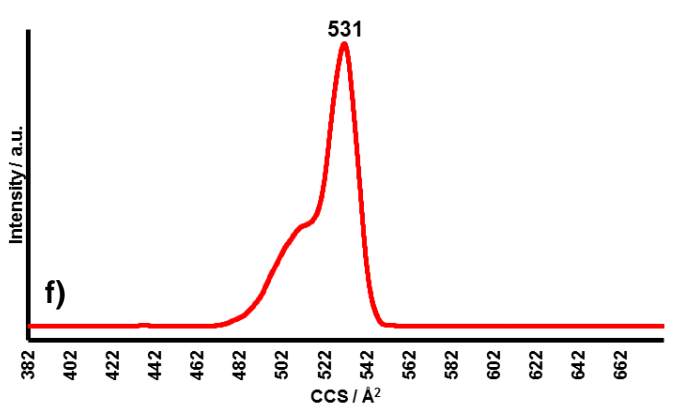

$[\mathrm{M}+\mathrm{Na}+\mathrm{H}]^{2+} \mathrm{m} / \mathrm{z} 1082$

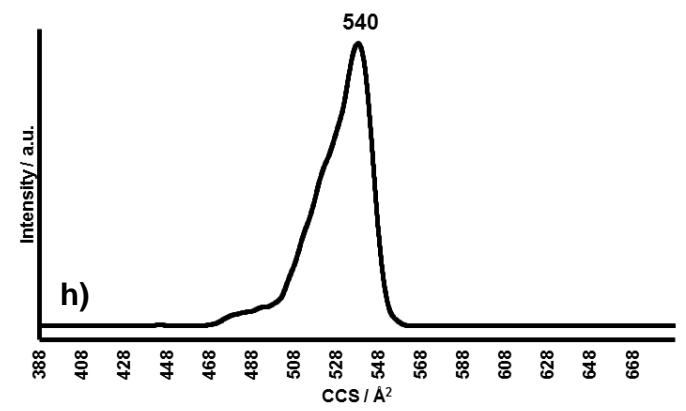

Figure S14. CCSD obtained for four EIC peaks A, B, C and D observed during intact IMS-MS analysis of CHO AAT released RFMS released $N$-glycans. a) CCSD of $m / z 1071[M+2 H]^{2+}$ for peak A b) CCSD of $m / z$ $1071[\mathrm{M}+2 \mathrm{H}]^{2+}$ for peak B c) CCSD of $m / z 1071[\mathrm{M}+2 \mathrm{H}]^{2+}$ for peak $\mathrm{C}$ d) CCSD of $m / z 1071[\mathrm{M}+2 \mathrm{H}]^{2+}$ for peak $D$ e) CCSD of $m / z 1082[\mathrm{M}+\mathrm{Na}+\mathrm{H}]^{2+}$ for peak A f) CCSD of $m / z 1082[\mathrm{M}+\mathrm{Na}+\mathrm{H}]^{2+}$ for peak $\mathrm{B} \mathrm{g}$ ) CCSD of $m / z 1082[\mathrm{M}+\mathrm{Na}+\mathrm{H}]^{2+}$ for peak $\mathrm{C}$ h) CCSD of $m / z 1082[\mathrm{M}+\mathrm{Na}+\mathrm{H}]^{2+}$ for peak $\mathrm{D}$. 


\section{$(2 x \bigcirc+1 x \square)$}
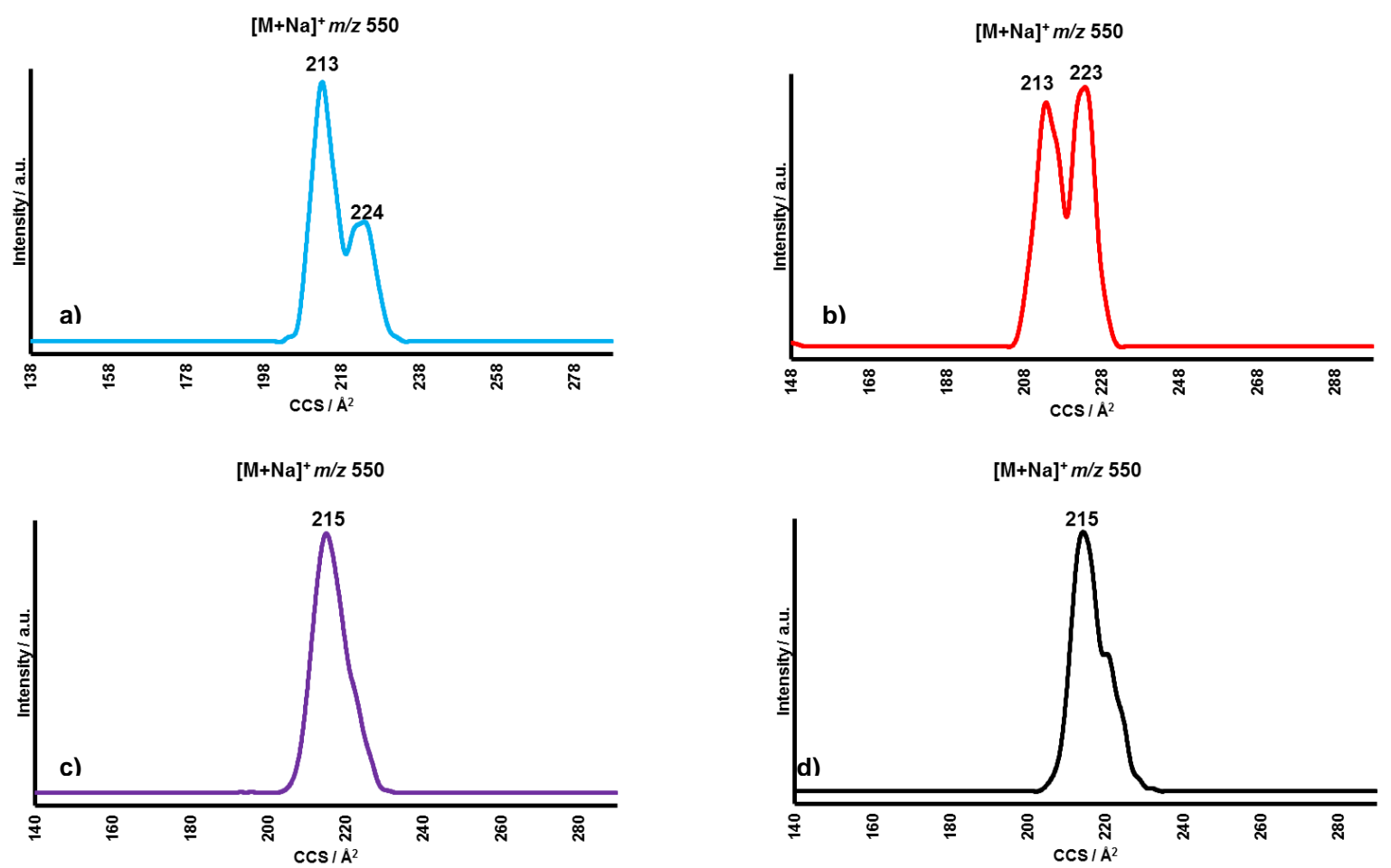

Figure S15. CCSD of $m / z 550$ product ion from precursor $m / z 1082[\mathrm{M}+\mathrm{Na}+\mathrm{H}]^{2+}$ of the four EIC peaks $A, B$, $C$ and D observed during RFMS glycan released anlaysis of CHO AAT glycans. a) CCSD of $m / z 550$ product ion from precursor $m / z 1082[\mathrm{M}+\mathrm{Na}+\mathrm{H}]^{2+}$ for peak $A$ b) $\mathrm{CCSD}$ of $\mathrm{m} / \mathrm{z} 550$ product ion from precursor $m / z 1082[\mathrm{M}+\mathrm{Na}+\mathrm{H}]^{2+}$ from peak B c) CCSD of $m / z 550$ product ion from precursor $m / z 1082$ $[\mathrm{M}+\mathrm{Na}+\mathrm{H}]^{2+}$ from peak $\mathrm{C}$ d) $\mathrm{CCSD}$ of $\mathrm{m} / \mathrm{z} 550$ product ion from precursor $\mathrm{m} / \mathrm{z} 1082[\mathrm{M}+\mathrm{Na}+\mathrm{H}]^{2+}$ from peak D. 
$(3 x \bigcirc+2 x \square)$
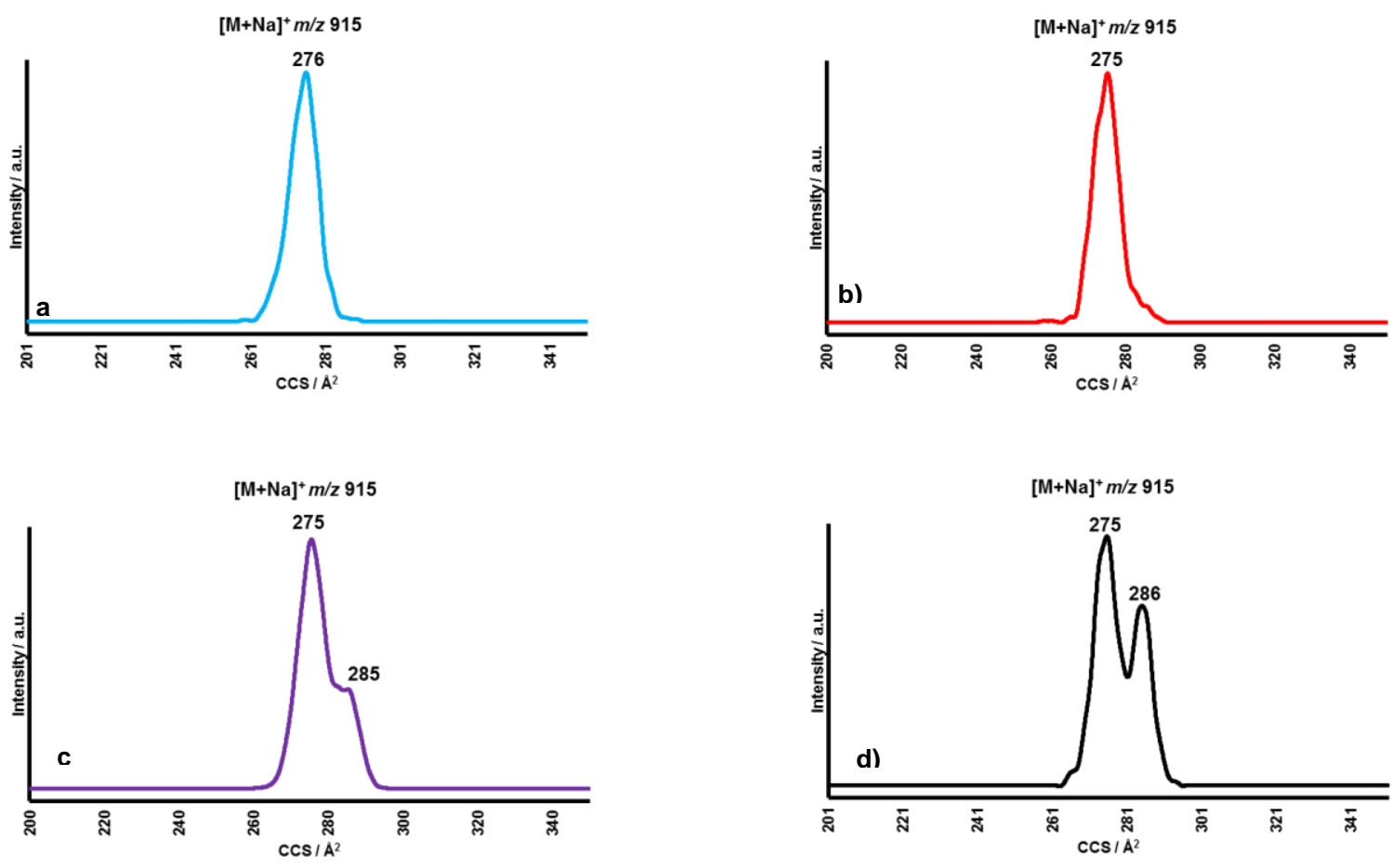

Figure S16. CCSD of $m / z 915$ product ion from precursor $m / z 1082[\mathrm{M}+\mathrm{Na}+\mathrm{H}]^{2+}$ of the four EIC peaks $\mathrm{A}, \mathrm{B}$, $C$ and D observed during RFMS glycan released anlaysis of CHO AAT glycans. a) CCSD of $m / z 915$ product ion from precursor $m / z 1082[\mathrm{M}+\mathrm{Na}+\mathrm{H}]^{2+}$ for peak $A$ b) $\mathrm{CCSD}$ of $m / z 915$ product ion from precursor $m / z 1082[\mathrm{M}+\mathrm{Na}+\mathrm{H}]^{2+}$ from peak B c) CCSD of $m / z 915$ product ion from precursor $m / z 1082$ $[\mathrm{M}+\mathrm{Na}+\mathrm{H}]^{2+}$ from peak $\mathrm{C}$ d) $\mathrm{CCSD}$ of $\mathrm{m} / \mathrm{z} 915$ product ion from precursor $\mathrm{m} / \mathrm{z} 1082[\mathrm{M}+\mathrm{Na}+\mathrm{H}]^{2+}$ from peak D. 


\section{Additional Results}

Having shown that we can identify the difference between the F(6)A2G1 and F(6)A2G1' isomers for both released glycans and glycopeptides we decided to see if any other isomer could be easily identified using IMS-MS analysis. Initially we were interested in seeing if we could determine the arm position of a sialic acid for F(6)A2G2S1 isomers (Figure S17) in a similar way to that described for the F(6)A2G1 isomers. F(6)A2G2S1 and F(6)A2G2S1' have the same glycan structure except that the position of the sialic acid is on the $\alpha 1,3$ arm of the glycan for $F(6) A 2 G 2 S 1$ or the $\alpha 1,6$ for $F(6) A 2 G 2 S 1$ ' (Figure S17). Initially we performed IMS-MS intact analysis of both F(6)A2G2S1 and F(6)A2G2S1' RFMS labelled glycans. Each isomer appeared to produce unique CCSDs for both the $[\mathrm{M}+2 \mathrm{H}]^{2+}$ and $[\mathrm{M}+\mathrm{Na}+\mathrm{H}]^{2+}$ species (Figure S18). A glycan sequencing IMS-MS/MS analysis was also carried out to see if we could identify any diagnostic fragments between these isomers. However, the glycan sequencing analysis was unable to identify any unique product ion CCSDs between the isomers in the IMS for either the $[\mathrm{M}+2 \mathrm{H}]^{2+}$ or $[\mathrm{M}+\mathrm{Na}+\mathrm{H}]^{2+}$. The main issue we faced was the labile nature of the sialic acids during the MS. As the sialic acids are so labile they only require a small amount of energy to induce fragmentation compared to the other sugars present in the glycan. This made obtaining any diagnostics fragments from glycan sequencing extremely difficult. Identifying arm sialic acid position on structures by conventional glycan sequencing for $\mathrm{F}(6) \mathrm{A} 2 \mathrm{G} 2 \mathrm{~S} 1$ and $\mathrm{F}(6) \mathrm{A} 2 \mathrm{G} 2 \mathrm{~S} 1$ ' isomers was therefore not possible. However, the results for the $\mathrm{F}(6) \mathrm{A} 2 \mathrm{G} 1 \mathrm{~S} 1$ isomers indicates a potential route to identifying the sialic acid arm preferences of $\mathrm{F}(6) \mathrm{A} 2 \mathrm{G} 2 \mathrm{~S} 1$ isomers. For example a $\beta 1-4$ galactosidase could be used to trim the unprotected galactose from $\mathrm{F}(6) \mathrm{A} 2 \mathrm{G} 2 \mathrm{~S} 1$ then analyze any resulting $\mathrm{F}(6) \mathrm{A} 2 \mathrm{G} 1 \mathrm{~S} 1$ species. In addition $\mathrm{MS}^{\mathrm{n}}$ type analysis could also be used. For example an initial fragmentation could be used to fragment off the labile sialic acid and galactose resulting in formation of $\mathrm{F}(6) \mathrm{A} 2 \mathrm{G} 1 \mathrm{~S} 1$ product ion. This product ion could then be fragmented again and the diagnostic $m / z, 712$ product ion CCSD analyzed. We did attempt this $\mathrm{MS}^{\mathrm{n}}$ type strategy however; the Waters Corp. Synapt G2-Si only has one collision cell before the ion mobility cell. Therefore we relied upon in source fragmentation (such as adjusting cone voltages) to perform the initial fragmentation. Relying on in source fragmentation made the analysis difficult and the results proved to be inconclusive. It would be interesting to see if this approach is successful on a true $\mathrm{MS}^{\mathrm{n}}$ ion mobility instrument. 
a)

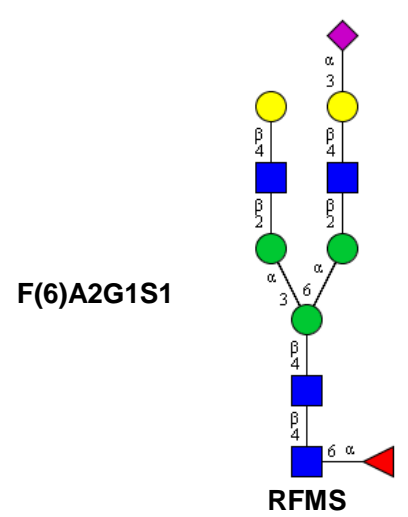

b)

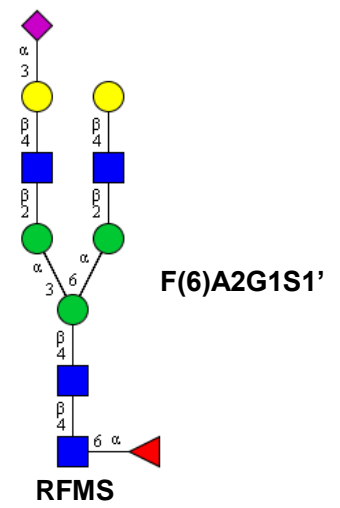

Figure S17. Sialylated glycan structures a) F(6)A2G2S1 b)F(6)A2G2S1' 

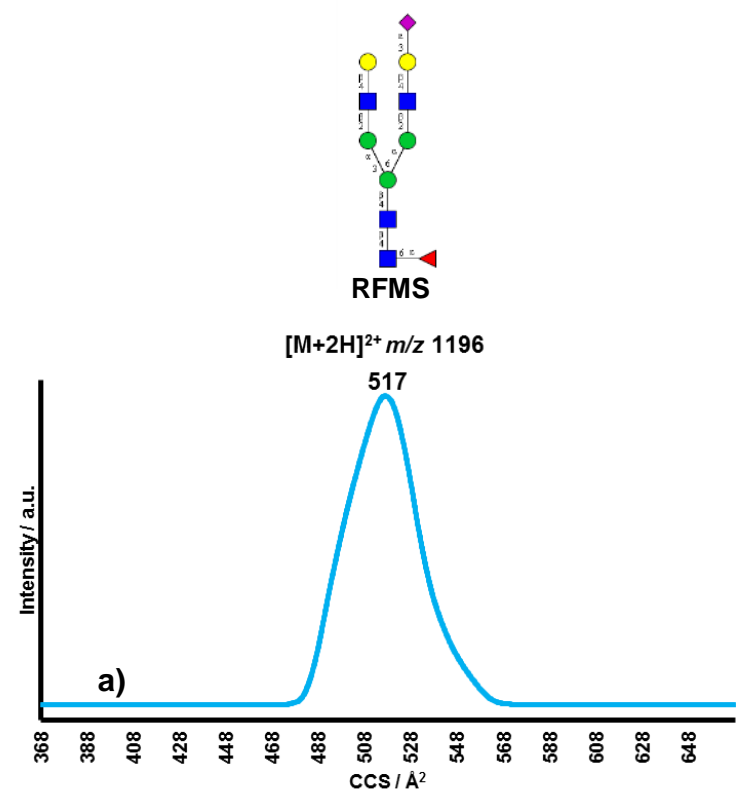

$[\mathrm{M}+\mathrm{Na}+\mathrm{H}]^{2+} \mathrm{m} / \mathrm{z} 1207$

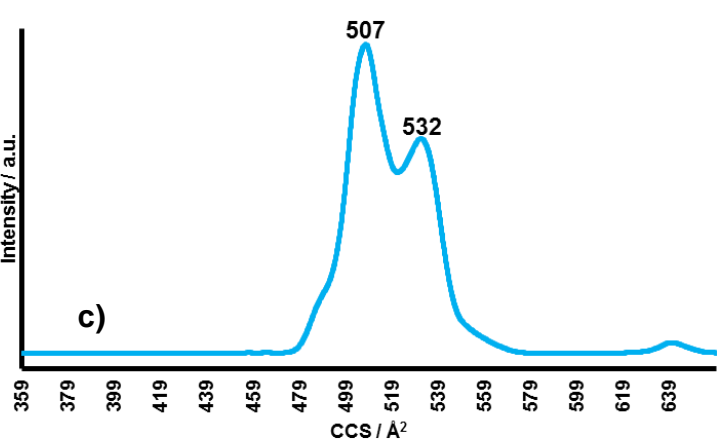

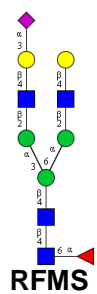

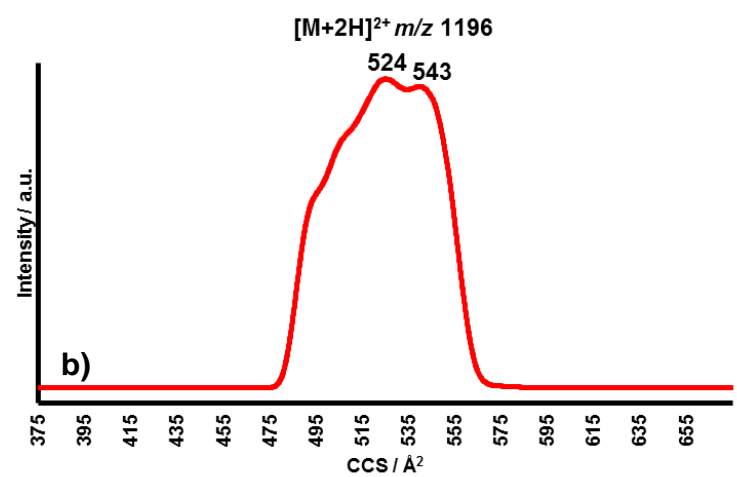

$[\mathrm{M}+\mathrm{Na}+\mathrm{H}]^{2+} \mathrm{m} / \mathrm{z} 1207$

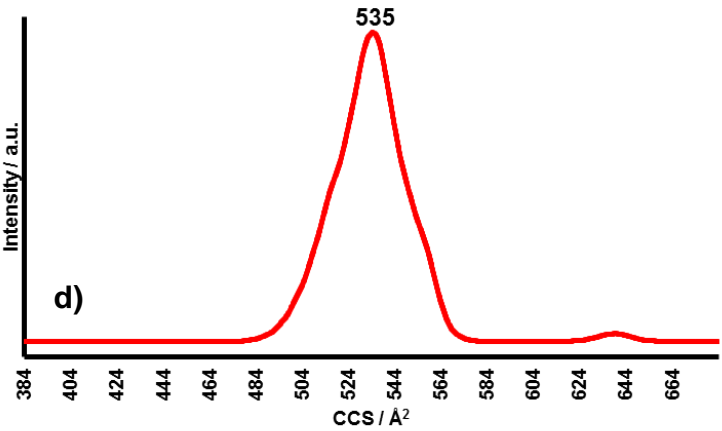

Figure S18. CCSD from IMS-MS intact analysis of a) $m / z 1196 \mathrm{~F}(6) A 2 G 2 S 1[M+2 H]^{2+}$ species b) $m / z$ $1196 \mathrm{~F}(6) A 2 \mathrm{G} 2 \mathrm{~S} 1^{\prime}[\mathrm{M}+2 \mathrm{H}]^{2+}$ species c) $m / z 1207 \mathrm{~F}(6) A 2 \mathrm{G} 2 \mathrm{~S} 1[\mathrm{M}+\mathrm{Na}+\mathrm{H}]^{2+}$ species d) $m / z 1207$ $\mathrm{F}(6) A 2 \mathrm{G} 2 \mathrm{~S} 1^{\prime}[\mathrm{M}+\mathrm{Na}+\mathrm{H}]^{2+}$ species . 


\section{Tables}

Table S1. All potential product ions with $\mathrm{m} / \mathrm{z} 712$ from fragmentation of $\mathrm{F}(6) \mathrm{A} 2 \mathrm{G} 1[\mathrm{M}+\mathrm{Na}+\mathrm{H}]^{2+}$ species $^{2}$

\begin{tabular}{|c|c|c|c|c|}
\hline Reference & Fragment & Ion Structure & $\begin{array}{c}\text { Theoretical } \\
\mathrm{m} / \mathrm{z}\end{array}$ & Adduct \\
\hline a) & $Y_{4} Y_{4} B_{5}$ & & 712.2 & $\mathrm{Na}$ \\
\hline b) & $Y_{4} B_{4}$ & & 712.2 & $\mathrm{Na}$ \\
\hline c) & $Y_{3} B_{4}$ & & 712.2 & $\mathrm{Na}$ \\
\hline d) & $\mathbf{Y}_{4} \mathbf{Y}_{5} \mathbf{B}_{4}$ & & 712.2 & $\mathrm{Na}$ \\
\hline e) & $\mathrm{Y}_{4} \mathrm{Z}_{4} \mathrm{C}_{5}$ & & 712.2 & $\mathrm{Na}$ \\
\hline f) & $\mathrm{Z}_{4} \mathrm{C}_{4}$ & & 712.2 & $\mathrm{Na}$ \\
\hline g) & $\mathrm{Z}_{3} \mathrm{C}_{4}$ & & 712.2 & $\mathrm{Na}$ \\
\hline h) & $\mathrm{Z}_{4} \mathrm{Y}_{5} \mathrm{C}_{4}$ & & 712.2 & $\mathrm{Na}$ \\
\hline
\end{tabular}




\begin{tabular}{|l|l|l|l|l|}
\hline i) & $\mathrm{Y}_{4} \mathrm{Z}_{5} \mathrm{C}_{4}$ & & & \\
& & & & \\
\end{tabular}

Table S2. All potential product ions with $\mathrm{m} / \mathrm{z} 712$ from fragmentation of $\mathrm{F}(6) \mathrm{A} 2 \mathrm{G} 1^{\prime}[\mathrm{M}+\mathrm{Na}+\mathrm{H}]^{2+}$ species. $^{2}$

\begin{tabular}{|c|c|c|c|c|}
\hline Reference & Fragment & Ion Structure & $\begin{array}{c}\text { Theoretical } \\
\mathrm{m} / \mathbf{z}\end{array}$ & Adduct \\
\hline a) & $Y_{4} Y_{4} B_{5}$ & & 712.2 & $\mathrm{Na}$ \\
\hline b) & $\mathbf{Y}_{4} \mathbf{B}_{4}$ & & 712.2 & $\mathrm{Na}$ \\
\hline c) & $\mathbf{Y}_{3} \mathbf{B}_{4}$ & & 712.2 & $\mathrm{Na}$ \\
\hline d) & $Y_{4} Y_{5} B_{4}$ & & 712.2 & $\mathrm{Na}$ \\
\hline e) & $\mathrm{Y}_{4} \mathrm{Z}_{4} \mathrm{C}_{5}$ & & 712.2 & $\mathrm{Na}$ \\
\hline f) & $\mathrm{Z}_{4} \mathrm{C}_{4}$ & & 712.2 & $\mathrm{Na}$ \\
\hline
\end{tabular}




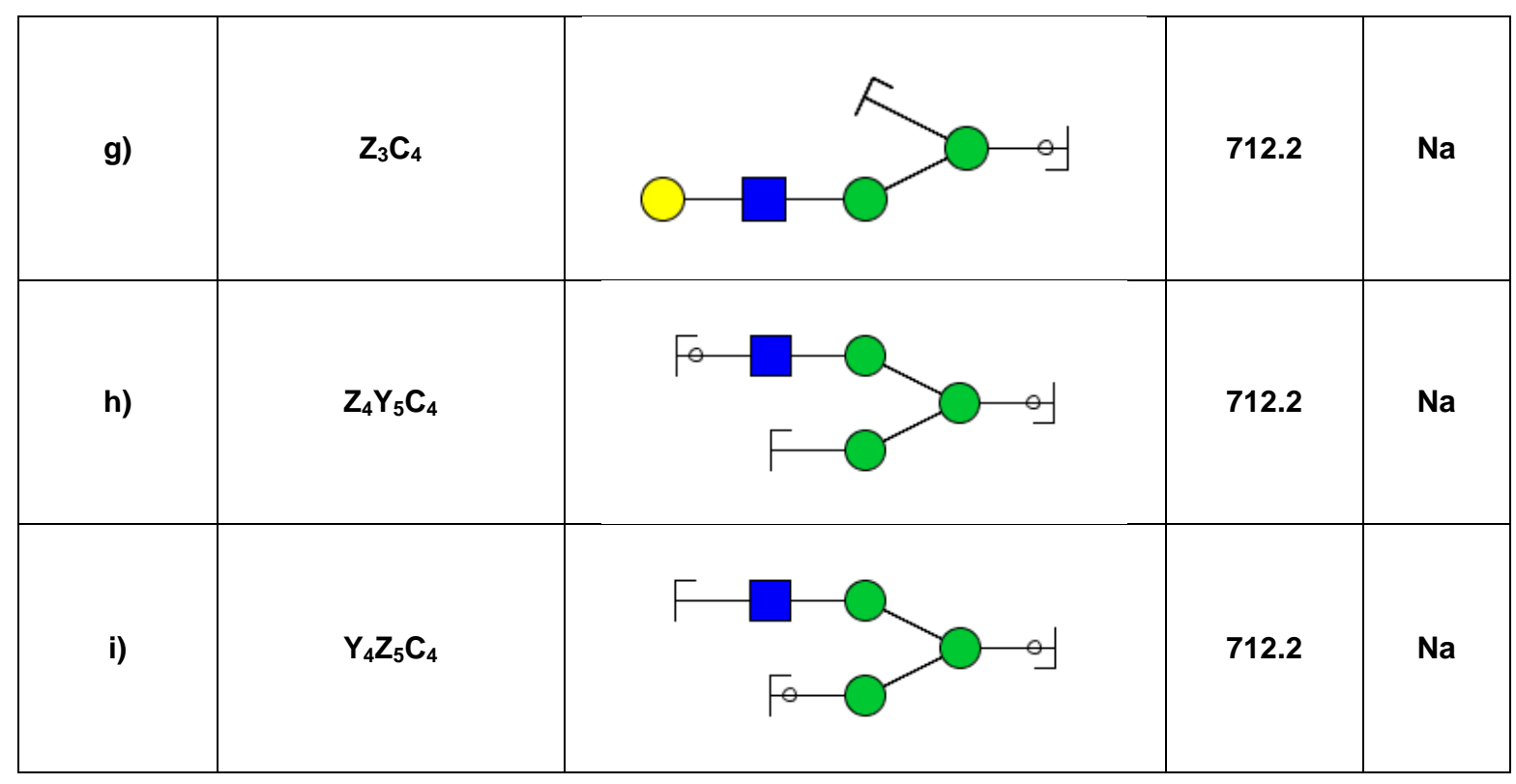

